\title{
Mutlu Fail Olgusu ve Çocukların Toplumsal Cinsiyet ve Etnisiteye Dayalı Akran Dışlanmasına Yönelik Yargıları
}

\section{Happy Victimizer Phenomenon and Children's Judgements on Peer Exclusion Based on Gender and Ethnicity}

\author{
Ayşe Yıldız ${ }^{1}$, Melike Acar ${ }^{2 *}$ \\ ${ }^{1}$ Uzm. Psikolog, Hisar Okulları, ayse.yildiz@hisarschool.k12.tr, https://orcid.org/0000-0001-9975-6219 \\ ${ }^{2}$ Dr. Öğretim Üyesi, MEF Üniversitesi, Eğitim Fakültesi, acarmel@mef.edu.tr, https://orcid.org/0000-0003- \\ 3233-1042
}

Geliş tarihi/Received : 21.02.2021 Kabul tarihi/Accepted: 09.12.2021 Yayın tarihi/Published: 30.12.2021

\begin{abstract}
ÖZET
Ahlaki ve sosyal sorgulamanın gelişiminde duyguların anlamlandırılması ve duygu atıflarının da önemli rol oynadığı bulunmuştur (Arsenio, 2014). Bu araştırmanın ilk amacı, çocukların toplumsal cinsiyet ve etnisite bağlamında akran dışlanmasına yönelik yargılarını incelemektir. Buna ek olarak erken çocukluk ve ilkokul yıllarının ilk yarısında gözlemlenen "Mutlu Fail" (Arsenio ve Lover, 1995; Keller vd., 2003) olgusunun Türkiye çalışma grubunda da görülüp görülmediği akran dışlanması bağlamında araştırmaktır. Araştırmada karma araştırma deseni kullanılmış, katılımcı çocuklarla çevirimiçi bir platform üzerinden birebir görüşmeler gerçekleştirilmiştir. Yapılan görüşmelerde özel bir ilkokulda ikinci sınıf öğrencisi olan toplam 24 (12 kız ve 12 oğlan) çocuk, cinsiyet ve etnisite bağlamlarında oyun grubundan dışlanmayı anlatan varsayımsal hikâyeleri değerlendirmişlerdir. İlk olarak çocuklara cinsiyet ve etnisite bağlamlarında bir oyun grubundan dişlanmaya yönelik yargı ve gerekçeleri sorulmuştur. Ayrıca, oyun grubunda sadece bir kişilik yer kaldığında çocukların akran tercihinin iç-gruptan mı, yoksa dış-gruptan yana mı olduğu araştırılmıştır. Sonuçlar, çocukların her iki hikâyede de oyun grubundan dışlanmayı olumsuz olarak değerlendirdiğini, çocukların cinsiyet ve etnisite bağlamlarında oyun grubundan dışlanmayı değerlendirirken ahlaki normları gerekçe olarak kullandıkları göstermektedir. Her iki hikâyede de çocuklar, oyun grubuna dahil olmayan çocuğa olumsuz duygular (örneğin, üzgün, yalnız) atfetmişlerdir. Öte yandan mutlu fail olgusu ortaya çıkmış, katılımcı çocukların hikâyedeki akranını dışlayan çocuklara olumlu duygular atfetmeye daha meyilli oldukları gözlenmiştir. Genel olarak bu çalışmanın sonuçları bize, katılımcı çocukların sosyal dışlanmayı değerlendirirken evrensel bir sorgulama örüntüsü kullandıklarını göstermektedir.
\end{abstract}

Anahtar Kelimeler: Sosyal dışlama, çocukların sosyal yargıları, mutlu fail, ahlaki duygular

\begin{abstract}
It has been found that the identifying of emotions and attribution of emotions play an important role in the development of moral and social reasoning (Arsenio, 2014). The primary purpose of this research was to examine children's judgments about peer exclusion in the context of gender and ethnicity. In addition, it investigated whether the phenomenon of "Happy Victimizer" (Arsenio and Lover, 1995; Keller et al., 2003) in the early childhood and first half of primary school years is also seen in the Turkish study group in the context of peer exclusion. The research used a mixed research design, and one-on-one interviews were conducted with the participating children over an online platform. In the interviews, a total of 24 (12 girls and 12 boys) second-year students in a private primary school evaluated hypothetical stories about being excluded from the playgroup in terms of gender and ethnicity. First, the children were asked about their judgments and reasons for being excluded from a playgroup regarding gender and ethnicity. In addition, it was investigated whether the children's peer preference was for the in-group or the out-group when there was only one room left in the playgroup. The results showed that children negatively evaluated being excluded from the playgroup in both stories. They use moral norms as justification when evaluating exclusion from the playgroup in terms of gender and ethnicity. In both stories, the children attributed negative emotions (e.g., sad, lonely) to the child who was not included in the playgroup. On the other hand, the happy victimizer phenomenon emerged. The participating children were more inclined to attribute positive emotions to children who excluded their peers in the story. In general, the results of this study reveal that the participating children use universal reasoning patterns when evaluating social exclusion. Keywords: Social exclusion, children's social judgments, happy victimizer, moral emotion
\end{abstract}




\section{GÍRIS}

Çocuklar sosyal dünyayı nasıl anlarlar, nasıl yorumlarlar sorusu günümüz gelişim psikologlarının araştırdıkları temel sorulardan biridir (Köymen ve Tomasello, 2017). Ancak, Türkçe alanyazın incelendiğinde çocukların özne olduğu sosyal-bilişsel gelişim araştırmalarına nadir rastlanmaktadır. Bu araştırmanın ilk amacı ilkokul ikinci sınıfa giden çocukların gözünden sosyal dışlanmanın nasıl değerlendirildiği ve dışlama pratiklerine hangi duyguları atfettiklerini Sosyal Alan Kuramı'nı (Turiel, 1983) kullanarak incelemektir.

Çocukların sosyal ve ahlaki sorgulamalarına yönelik ilk bilişsel gelişim kuramı Jean Piaget (1932) tarafindan geliştirilmiştir. Piaget, ahlak gelişimini bilişsel gelişimle paralel açıklamakta, adalet ve karşılıklı saygı prensipleriyle tanımladığ 1 otonom ahlakın ancak eşitler arası akran ilişkilerinde gelişebileceğini vurgulamaktadır. Piaget, 5-9 yaş arasındaki çocukların otoriteden bağımsız bir ahlaki sorgulama yürütemediklerini ve otorite tarafından konulmuş her kuralın eşit derecede önemli ve çiğnenemez olduğunu düşünmektedirler (Piaget, 1932). Bir diğer yapılandırmacı gelişimsel yaklaşım olan Kohlberg'ün kuramında da ahlak en yalın ifadeyle, neyin doğru neyin yanlış sayıldığı ya da sayılması gerektiği ile ilgili akıl yürütme süreci olarak tanımlanır ve bilişsel gelişim aşamalarıyla doğrudan ilişkilendirilir (Kohlberg, 1969). Bu aşamalı sınıflandırma sistemleri kullanılarak ülkemizde yapılan yakın tarihli bir çalışmada, ilkokul çocuklarının gelenek öncesi dönemde olduğu bulunmuştur (Yaşartürk, 2019). Öte yandan sosyal-bilişsel gelişim alanında özellikle son 40 yılda yapılan bilimsel çalışmalar, Piaget ve Kohlberg'ün bulgularının aksine, çocukların aslında 3 yaşından itibaren otorite ve otoritenin koyduğu kurallar hakkında akıl yürüttüğünü ve evrensel ahlaki normları diğer sosyal kurallardan ayrıştırdığını göstermektedir (Turiel, 2015). Bu çalışmanın da kuramsal çerçevesi olan Sosyal Alan Kuramına göre, sosyal bilgilerin alanları tanımsal bazı kriterler üzerinden farklılaşır (Turiel, 1983). Bu kuram, ötekinin iyi oluş hali, adalet, eşitlik ve haklar üzerine yargıların dayandırıldığı ahlaki alan, sosyal organizasyonel işleyiş̧i sağlayan toplumsal-geleneksel alan ve bireylerin kendi olmalarına olanak sağlayan kişisel-psikolojik alan olmak üzere, üç farklı toplumsal bilgi türünün epistemolojik olarak farklılığını vurgular (Smetana, 2005). Ahlaki alan, Piaget'nin otonom ahlak tanımindan (Piaget, 1932) yola çıkılarak, bireylerin ilişkilerinde karşılarındaki kişinin iyi oluş ve haklarını herhangi bir otorite baskısı ve ceza korkusu olmadan gözetmesi olarak tanımlanmaktadır (Turiel, 1983). Toplumsal-geleneksel alan ise, sosyal bir varlık olan insanın, sosyal yaşamda ihtiyaç duyduğu düzenlemeleri, kuralları ve bu kuralları uygulama biçimlerini bağlam ve durumlara göre inceleyen bir alandır (Smetana, 1981). Sosyal alan kuramında, özellikle çocukların erken çocukluk yıllarından itibaren toplumsal-geleneksel alan ile ahlak alanının ayrımını evrensel olarak fark edebilmeleri gelişim psikoloji alanına yeni bir katkı sağlamıştır. Bu kuramla yapılan araştırmalar bize toplumsal bilginin üç alanından biri olan ahlak alanında, çocukların etkileşime girdikleri insanların hakları ve iyi oluş halleri ile sonuçlanan eylemleri yorumlayarak, bu eylemlerden çıkarımlar yaparak ahlaka ilişkin düşünceler geliştirdiklerini göstermektedir (Smetana, 1981). Çocuklar, kendi deneyimlerine dayanarak ötekinin de iyi olması için zarar verici davranışlardan uzak durma gibi ahlaki bir anlayış ve yargı oluşturmaktadırlar. Yapılan araştırmalarda çocuklar, başkasına ait bir eşyayı izinsiz eve götürmenin ötekini üzeceği için yanlış olduğunu ve buna yönelik kuralın da evrensel olması gerektiğini söylemektedirler (Smetana, 1989; Turiel, 1983). Çocukların toplumsal-geleneksel alana yönelik sorgulamalarında ise, ortak deneyimler ve etkileşimler neticesinde düzenlenmiş ve yine üzerinde ortak yargıya ama daha çok otorite figürlerince belirlenmiş beklentilere ve kurallara referans verdikleri görülür (Turiel, 1983). Sosyal bir varlık olarak çocuklar, gelişim süreçlerinde yetişkinleri gözlemleyerek ve dinleyerek birtakım doğrular, yargılar ve değerlendirmeler geliştirirken, toplumsal-geleneksel kuralların yetişkinler ve toplumun işleyişi için önemli olduğunun da farkına varırlar, ancak bu kuralların bağlamdan bağlama 
değişebileceğine yönelik değerlendirmeler yaparlar (Smetana, 2005). Kişisel-psikolojik alan ise, çocukların kendini, kimliğini, kişiliğini ve psikolojik ihtiyaçlarını anlama ve yorumlama durumlarını içermektedir. Bu alana yönelik yapılan sorgulamalar doğru ya da yanlış gibi normlara değil, kişisel seçime dayandırılır (Nucci 1981).

Batı ülkelerinde Sosyal Alan Kuramı ile yapılan araştırmalar bize, çocukların toplumsal cinsiyete ve etnisiteye dayalı doğrudan ayrımcılığı ahlaki açıdan açıkça kınadıklarını, ancak çetrefilli durumlarda, örneğin sadece bir kişiyi seçmek zorunda oldukları durumlarda, ötekinin dışlanmasını grubun işleyişi, toplumsal kalıp yargıları ve grubun normları gibi toplumsalgeleneksel alanın kriterlerine dayanarak gerekçelendirip açıkladıklarını göstermektedir (Killen, Mulvey ve Hitti, 2013; Ruthland ve Killen, 2013).

Öte yandan, ahlaki yargılar ve ahlaki duyguların gelişimi arasındaki ilişsiyi inceleyen araştırmaların sayısı da artmaktadır. Bu çalışmalarda öne çıkan kavramlardan biri de "Mutlu Fail" (happy victimizer) olgusudur. Araştırma sonuçları, dört-sekiz yaş arası çocukların ahlaki norm ihlali yapan faile olumlu duygular atfettiklerini göstermektedir (Arsenio ve Krammer, 1992; Gummerum vd., 2016; Keller vd., 2003). Bir başka deyişle, bu yaş aralığındaki çocuklar, bir çocuğun arkadaşını salıncaktan itmesini ahlaken yanlış bir davranış olarak değerlendirmelerine rağmen iten çocuğun amacına ulaşıp salıncağa bindiği için mutlu hissedeceğini söylemektedirler. Ancak, sekiz yaşından itibaren ahlaki bir normu bilerek isteyerek ihlal eden faile suçluluk, vicdan azabı, üzüntü gibi duygular atfetmeye başladıkları görülmüştür. Ülkemizdeki alanyazın incelendiğinde zorbalık üzerine yapılmış pek çok çalışma olduğu saptanmıştır. Ancak bu çalışmalarda zorbalık davranışı, şiddet eğilimi ve dürtü kontrolü güçlügü gibi, sadece bireysel psikolojik özelliklere indirgenerek zorbalık yapmaya ve zorbalığa maruz bırakılmaya eğilimli çocukların tespiti amaçlanmıştır (Bayraktar, 2006). Bu noktada, çocukların bakış açısını hem ayrımcılık yapanın, zorbalığa yatkın olanın hem de ayrımcılığa maruz bırakılanın bakış açısından değerlendirildiği sosyal-bilişsel gelişim odaklı Türkiye'de yapılmış karma desenli bir çalışmaya rastlanmamıştır.

Bu çalışma, Sosyal Alan Kuramından yola çıkarak ilkokul ikinci sınıfa giden çocukların içinde yetişmiş oldukları kültürde, birini oyun grubuna dahil etmeme-dışlama davranışını, toplumsal cinsiyet ve etnisite bağlamlarında nasıl değerlendirdikleri ve bu değerlendirmelerinin gerekçelerini incelemeyi amaçlamaktadır. Çalışmanın ana odağı, benzer değerlendirme örüntülerinin Türkiye'de seçilmiş çalışma grubunda olup olmadığını araştırmaktır. Bu doğrultuda aşağıdaki beş soruya cevap aranacaktır:

1. Araştırmaya katılan çocuklar, bir akranı oyun grubuna dahil etmeme-dışlama davranışını nasıl değerlendiriyor? Dışlanmanın toplumsal cinsiyet ve etnisite dayalı olduğu iki durumda çocukların değerlendirmelerinin dağılımı nasıldır?

2. Çocukların değerlendirmelerine yönelik sundukları gerekçeler hikâyenin bağlamına göre nasıl dağıliyor?

3. Oyuncakların sınırlı sayıda olduğu durumda, çocuklar oyun grubuna kimi seçiyorlar ve bunu nasıl gerekçelendiriyorlar?

4. Çocuklar, dışlayanlara ve dışlananlara hangi duyguları atfediyorlar?

5. Katılımcı çocuklar, duruma dışlanan çocuk bakış açısından baktıklarında ne gibi çözüm önerileri getiriyorlar? 


\section{YÖNTEM}

\section{Araştırmanın Modeli}

$\mathrm{Bu}$ araştırmada nicel ve nitel araştırma yöntemlerinin bir arada kullanıldığı karma araştırma deseni kullanılmıştır. Karma desende, nicel ve nitel veri toplama ve analiz yöntemleri birlikte kullanılır (Creswell ve Clark, 2017).

\section{Çalışma Grubu}

Bu çalışmaya ilkokul ikinci sınıfına devam eden ve anadili Türkçe olan, 12 kız, 12 oğlan olmak üzere toplam 24 çocuk ( $\overline{\mathrm{x}}=7$ yaş, 4 aylık, $\mathrm{SS}=3.64)$ katılmıştır. Yaş ortalaması kızlar için 7 yaş, 6 ay $(\mathrm{SS}=3.03)$, oğlanlar için 7 yaş, 2 aydır $(\mathrm{SS}=3.99)$. Çalışmaya katılan çocukların tamamı İstanbul'da özel bir okula devam etmektedir. Katılımcı çocukların anne ve babalarının tamamı en az 4 yıllık üniversite mezunudur.

\section{Verilerin Toplanması}

Çocuklarla yapılacak görüşmeler yüz yüze olacak şekilde planlanmıştır. Ancak, COVID19 salgını nedeniyle öğrencilerin eğitim-öğretim süreçleri ve yöntemlerinde Milli Eğitim Bakanlığı tarafından yapılan düzenlemeler neticesinde, 2020-2021 akademik yılına uzaktan eğitim ile devam edilmiştir. Bu nedenle, planlanan görüşmeler çevrimiçi ortamda birebir olarak düzenlenmiştir. Görüşmelerde katılımcılara varsayımsal hikâyeler sunulmuş ve onlardan durumları değişik bakış açılarından değerlendirmeleri, değerlendirmelerini gerekçelendirmeleri istenmiştir. Yapılan görüşmeler yazıya dökülüp geliştirilen kodlama şemasına göre kodlanmıştır.

Çocuklarla yapılacak görüşmelere başlanmadan, hikâyeler ve sorular MEF Üniversitesi İnsan Araştırmaları Etik Komitesi'nin 13.05.2019 tarihli toplantısında incelenmiş ve onaylanmıştır. Aynı zamanda çocukların devam etmekte olduğu özel okulun yönetim ve etik kurullarından da izin alınmıştır. Bu süreçten sonra veli onam formu velilere gönderilmiştir. Velileri tarafından çalışmaya katılmasına onay verilen çocuklarla yapılan çevirim içi görüşmelerin ses ve görüntü kayıtları alınmıştır. Gizliliği ve güvenliği korumak adına, alınan kayıtlar kimseyle paylaşılmadan deşifre edilmiş ve sonrasında silinmiştir. Deşifrelerde ve analizlerde çocukların kimliğini ortaya çıkaracak hiçbir bilgi kullanılmammıştır.

Çevrimiçi yapılan her bir görüşme için yaklaşık olarak 15-20 dakika ayrılmıştır. Çocuklara, devam etmek istemedikleri ya da soruyu yanıtsız birakmak istedikleri durumlarda kesinlikle 1srar edilmemiştir. Katılımcı çocukların sorulara cevap vermeleri beklenmiş, onları rahatsız edecek, yönlendirici, acele ettirici her türlü tavırdan özenle kaçınılmıştır. Hikâyeler okunmadan önce çocuklara, anlatılacak hikâyelere dair sorulan soruların doğru ya da yanlış cevaplarının olmadığı ve sadece hikâyelerdeki sorularla ilgili kendi fikirlerini ve değerlendirmelerini paylaşmalarının yeterli olduğu, istemediği soruyu cevaplamama hakkına sahip oldukları söylenmiştir.

\section{Veri Toplama Araçları}

Bu çalışmada kullanılan varsayımsal hikâyeler Theimer, Killen ve Stangor (2001), Killen, Mulvey ve Hitti (2013), Killen ve Stangor (2001) araştırmalarında kullanılan hikâyelerden ve değerlendirme sorularından esinlenerek geliştirilmiştir. Dışlayan ve dışlanana yönelik duygu atıfları soruları ise Arsenio ve Lover'ın (1995) çalışmasından alınmıştır. Hikâye sunumlarına durumu tasvir eden çizimler de eklenmiştir. Çocuklara anlatılan her hikâyede iki farklı durumu değerlendirmeleri istenmiştir. İlk hikâyenin bağlamı, toplumsal cinsiyet ve buna bağlı toplumsal cinsiyet kalıp yargılarına dayandırılarak karşı cinsten akranın dışlanmasıdır. $\mathrm{Bu}$ bağlamda kız çocuklarına, bebeklerle oynayan bir grup kız ve oyuna katılmak isteyen bir 
oğlanın kızlar tarafından dışlandığı hikâye sunulmuştur. Oğlanlar ise, kamyonlarla oynarken oyunlarına katılmak isteyen bir kız çocuğunun dışlanmasını değerlendirmişlerdir ve gerekçelerini söylemişlerdir. Daha sonra katılımcı çocuklar, hem dişlayan hem de dişlanan çocuğun duygularını tahmin etmeye çalışmışlardır. Hikâye görselinde de, bir grup hemcins çocuğun oyun oynamakta olduğu ve karşı cinsten bir akranın bu çocukların yanlarına gelip oyuna katılmak istediği resmedilmiştir. Hikâye şu şekilde devam etmektedir: "Grup içinden bir çocuk (Selin), karşı cinsten çocuğu (Kerem) oyuna dahil etmek istemez ve gidip oğlanlarla oynamasını söyler." hikâye okunduktan sonra katılımcı çocuklara Selin'in Kerem'i dışlaması uygun mudur diye sorulmuş ve sonrasında "neden?" sorusu yöneltilerek cevaplarını gerekçelendirmeleri istenmiştir.

$\mathrm{Bu}$ sorudan sonra, aynı hikâyelerin oyuncakların sınırlı olduğu versiyonu şu şekilde sunulmuştur. Örneğin oyuncak bebeğin limitli olduğu hikâye şu şekildedir: "Bir grup kız çocuk, bebeklerle oynamaktadır ve bebek sayısı limitlidir. Selin (hemcins) ve Kerem (karşı cins), aynı anda oyun grubuna yaklaşırlar ve oyuna katılmak istediklerini söylerler. Oyunda sadece bir oyuncak bebek boştadır ve oyuna sadece bir kişiyi seçmeleri gerekmektedir." Hikâye okunduktan sonra katılımcı çocuklara ilk önce "Sence kimi seçerler, Kerem'i mi, yoksa Selin'i mi?" sorusu yöneltilmiştir. Daha sonra katılımcılardan yaptıkları seçimi gerekçelendirmeleri istenmiştir. Son olarak da "Dışlayan ve dışlanan çocukların yerinde olsan ne hissederdin?" ve "Böyle bir durumda sen olsaydın, ne yapardın?" sorularıyla katılımcıların kendilerine yönelik yansıtma yapmaları istenmiştir.

İkinci hikâyede ise, katılımcılardan akranın oyun grubundan dışlanması davranışını etnisite bağlamında değerlendirmeleri istenmiştir. Bu hikâyede çocuklar, sınıflarında serbest oyun zamanında karışık gruplarda oyun oynamaktadır. Sınıflarına ailesi Türkiye'ye yerleşmek zorunda kalan Rana isimli bir öğrenci gelmiştir. Rana, Türkçe'yi sınıftaki diğer çocuklar gibi akıcı konuşamamaktadır. Bir grup çocuk sınıfın oyun köşesinde bloklarla oynamaktadır. Yeni çocuk Rana, grup halinde oynayan çocukların yanlarına yaklaşarak onlarla birlikte oynamak istediğini söyler, ancak çocuklar Rana'yı oyuna istemediklerini söylerler. Toplumsal cinsiyet hikâyesinde sorulan soruların aynısı, aynı sirayla bu hikâyeden sonra da aynı sırayla sorulmuştur.

\section{Verilerin Analizi ve Güvenirliliği}

Değerlendirmeler için kodlama şemaları, yazıya dökülen görüşmeler tek tek okunup çocukların verdikleri cevaplara göre oluşturulmuştur. Çocukların her iki hikâyede de akranını oyun grubuna dahil etmeme-dışlama davranışına yönelik değerlendirmeleri üç kategoride kodlanmıştır: (0) hayır, uygun değil, (1) biraz uygun, duruma göre değişir, (2) evet, uygun. Çocukların, oyuncakların sınırlı sayıda olduğu durumda kimi seçersin sorusuna verdikleri cevapları ise üç kategoride kodlanmıştır: (0) kendiyle aynı olanı seçer, (1) ötekini seçer, (2) her ikisini seçmek için ortam yaratmaya çalışır. Değerlendirmeler, makalenin birinci yazarı ve araştırmanın sorularına kör bir başka araştırma asistanı tarafından kodlanmıştır. Bu iki bağımsız kodlama arasında uyum oranı 90 Cohen Kappa olarak hesaplanmıştır.

Deşifre edilen görüşmelerde çocukların sunduğu gerekçeler Tablo 1'de gösterilen kodlama kriterlerine göre bağımsız iki kodlayıcı tarafından kodlanmıştır. Kodlama şeması, Sosyal Alan Kuramı kullanılarak yapılan benzer araştırmaların (Arsenio ve Kramer, 1992; Killen, Mulvey ve Hitti, 2013) kodlama şeması dikkate alınarak geliştirilmiştir. Araştırmanın kodlama kategorileri de hem birinci yazar hem de bağımsız araştırma asistanı tarafından kodlanmış ve bağımsız kodlamalar arasındaki uyum .80 Cohen Kappa olarak hesaplanmıştır. Çocukların dışlayana ve dışlanana yönelik duygu atıfları ise, (1) üzgün; (2) kızgın; (3) şaşkın ve (4) mutlu şeklinde kodlanmıştır. 
Bu çalışmada, veriler sosyal-bilişsel gelişim araştırmalarında sıklıkla kullanılan bire bir klinik görüşme yöntemiyle toplanmıştır (Mayer, 2005). Bu yöntem, aynı zamanda araştırmanın teorik çerçevesi olan Sosyal Alan Kuramı tarafindan da benimsenen, çocuklarda ve yetişkinlerde sosyal ve ahlaki sorgulamanın gelişimini yapılandırmacı bakış açısından analiz etmeye olanak sağlayan bir yöntemdir. Katılımcı sayısının azlığ nedeniyle bu çalışmada betimsel istatistiksel yöntemler kullanılmıştır. Nitel verinin bu şekilde kodlanarak nicel veriye dönüştürülüp analiz edilmesi yöntemi Sosyal Alan Kuramı kullanılarak yayınlanmış diğer araştırmalarla tutarlıdır (Killen, Lee-Kim, McGlothin, Stangor ve Helwig, 2002). Çalışmaya katılan çocukların ebeveynlerinden çocuklardan araştırmaya katılım formu doldurmaları istenmiş, onay verenler kendi eğitim bilgilerini ve çocuğun doğum tarihini içeren kısa bir demografik form doldurmuşlardır.

Tablo 1. Gerekçeler İçin Kodlama Şeması

\begin{tabular}{|c|c|c|}
\hline Alan & Kriter & Örnek \\
\hline Ahlaki & $\begin{array}{l}\text { Adalet } \\
\text { Haklar } \\
\text { İyi oluş hali }\end{array}$ & $\begin{array}{l}\text { "Adil olmaz, eşitliği bozar." } \\
\text { "Her çocuğun oyun oynama hakkı vardır." } \\
\text { "Diğeri seçilmezse üzülür." }\end{array}$ \\
\hline $\begin{array}{l}\text { Sosyal-geleneksel } \\
\text { kurallar }\end{array}$ & $\begin{array}{l}\text { Toplumsal beklentiler } \\
\text { Kalıp yargilar } \\
\text { Toplumsal cinsiyet } \\
\text { rolleri }\end{array}$ & $\begin{array}{l}\text { "Kızlar ve oğlanlar birlikte oynamak zorunda } \\
\text { değil." } \\
\text { "Herkes kendi grubuyla, kendi gibi olanla oynar." } \\
\text { "Kızlar bebeklerle oynar, arabalar erkekler daha } \\
\text { çok sever." }\end{array}$ \\
\hline Grup fonksiyonu & $\begin{array}{l}\text { Grubun iyiliği ve } \\
\text { çkarları }\end{array}$ & $\begin{array}{l}\text { "Oyunu daha iyi bileni seçerler." } \\
\text { "Kimin dilini daha iyi anlıyorlarsa onu seçerler." } \\
\text { "Kendi gibi olanı seçer, çünkü daha önce de } \\
\text { oynadılar." }\end{array}$ \\
\hline
\end{tabular}

Kişisel

Kişisel tercih

"Kimi isterse onu seçer, karışamayız."

\section{BULGULAR VE TARTIŞMA}

Çocukların toplumsal cinsiyet ve etnisite bağlamlarında akranını oyun grubuna dâhil etmemedışlama durumlarını değerlendirmelerini, bu değerlendirmeleri gerekçelendirmelerini ve dışlayan- dışlanan çocuklara yönelik duygu atıflarını yapılandırmacı bakış açısıyla incelemeyi amaçlayan bu araştırmanın bulgularının Sosyal Alan Teorisinin kullanıldığı önceki araştırmalarla tutarlı olup olmadığı araştırılmıştır (Killen ve Ruthland, 2013). Bulgular, giriş bölümünde belirlenen araştırma sorularının sırasıyla analiz edilmiştir.

Tablo 2. Çocukların Varsayımsal Hikâyelerdeki Akranın Oyun Grubundan Dışlanmasını Değerlendirmesi

\begin{tabular}{llll} 
& Uygun değil & Biraz uygun & Uygun \\
\hline Cinsiyet & $\% 75(\mathrm{~N}=18)$ & $\% 25(\mathrm{~N}=6)$ & --- \\
Etnisite & $\% 83(\mathrm{~N}=20)$ & $\% 13(\mathrm{~N}=3)$ & $\% 4(\mathrm{~N}=1)$ \\
\hline
\end{tabular}

1. Çocukların akran dışlanmasına yönelik değerlendirmeleri. Araştırmaya katılan çocukların çoğu toplumsal cinsiyet rollerine (\%75) ve etnisiteye dayalı (\%83) akran dışlanmasını uygun bulmadıklarını söylemektedirler. Ancak Tablo 2'de gösterildiği gibi katılımcıların, toplumsal cinsiyet rollerine dayalı dışlamayı, etnisiteye bağlı dışlanmadan daha olumlu değerlendirmiş oldukları bulunmuştur. Ayrıca katılımcı çocukların toplumsal cinsiyete dayalı dışlanmaya yönelik değerlendirmeleriyle etnisiteye dayalı dışlanmaya yönelik değerlendirmeleri arasındaki 
uyum incelenmiştir (Bknz Tablo 3). Katılımcıların \%71 ( $\mathrm{N}=17)$ her iki bağlamdaki dışlama davranışını olumsuz değerlendirirken, sadece \%8'i $(\mathrm{N}=2)$ akran dişlamayı iki bağlamda da biraz uygun olarak değerlendirmiştir (Bknz Tablo 3). Geriye kalan \%21'i (N=7) ise iki bağlamı farklı değerlendirmiştir. Bunların \%4'i $(\mathrm{N}=1)$ toplumsal cinsiyet bağlamında akran dışlanmasını biraz uygun bulurken, aynı çocuk etnisite bağlamında dışlamayı uygun bulmuştur. Aynı şekilde etnisite bağlamında dışlamayı biraz uygun değerlendiren bir diğer çocuk $(\% 4, \mathrm{~N}$ $=1$ ) toplumsal cinsiyet bağlamında dışlanma uygun değil demiştir.

Tablo 3. Katılımcıların Değerlendirmelerinin Hikâyeler Arasındaki Uyumu

\begin{tabular}{lcc}
\hline & $\mathrm{N}$ & $\%$ \\
\hline $\begin{array}{l}\text { İki hikâyede de uygun değil diyenler } \\
\text { İki hikâyede de biraz uygun diyenler }\end{array}$ & 17 & 71 \\
$\begin{array}{l}\text { Toplumsal cinsiyet bağlamında biraz uygun derken, } \\
\text { etnisitede uygun değil diyenler }\end{array}$ & 2 & 8 \\
$\begin{array}{l}\text { Etnitise bağlamında biraz uygun, toplumsal cinsiyet } \\
\text { için uygun değil }\end{array}$ & 1 & 4 \\
Sadece cinsiyet bağlamında biraz uygun & 1 & 4 \\
Sadece etnik bağlamda uygun diyenler & 2 & 8 \\
Toplam & 1 & 4 \\
\hline
\end{tabular}

2. Gerekçeler. Katılımcı çocuklar, dışlamayı her iki bağlamda da ahlaki gerekçelerle olumsuz bulduklarını söylemişlerdir (Tablo 4). Örneğin, çocuklar cinsiyete dayalı dışlama hikâyesinde akranı oyuna dahil etmeme-dışlama davranışlarını ahlaki (\%71) sorgulamalar yaparak "Uygun değil, çünkü erkekler erkeklerle kuzlar kızlarla oynayacak diye bir şey yok.", "Uygun değil, çünkü herkes herkesle oynayabilir ve klzlar da arabayla oynayabilir. Erkek de Barbie ile oynayabilir. Erkeğin oynamasına izin vermezlerse o üzülür, herkes üzülür.”, "Uygun değil, çünkü kız ya da erkek ayrımı olursa o zaman Dünya doğru düzgün bir yer olmaz." şeklinde ifade etmişlerdir. Bu alıntılar çalışma grubundaki çocukların toplumsal cinsiyetle ilgili kalıp yargıları sorguladıklarını ve eşitlik fikrini ön plana çıkardıklarını göstermektedir ve konuyla ilgili yapılmış diğer çalışmalarla da tutarlıdır (Killen ve Ruthland, 2013).

Öte yandan, etnisiteye dayalı hikâyede, oyunda akranı dışlama davranışı, araştırmaya katılan çocuklar tarafından değerlendirilirken çocukların, ahlaki gerekçelere daha sık başvurdukları (\%75) görülmektedir. "Uygun değil, çünkü diğer ülkelerden gelen çocuklar da herkesle oynayabilirler.", "Uygun değil, çünkü kimse dış görünüşünden ibaret değil, oynamayı bir denesinler. "Uygun değil, çünkü diğeri yeni gelmiş ve kendini yalnız hissediyor” ifadeleriyle çocuklar etnisiteye dayalı dışlamanın uygun olmadığını dile getirmişlerdir.

Çocukların sadece küçük bir bölümünün toplumsal cinsiyet bağlamına yönelik hikâyede, akranı oyun grubuna dahil etmeme davranışını yorumlarken, toplumsal-geleneksel kurallara dayalı değerlendirmelere $(\% 17)$ ve grubun fonksiyonuna yönelik değerlendirmelere (\%8) başvurduğu görülmüştür. Çocukların azınlık bir kısmı ise (\%4) bu hikâyeyi değerlendirirken kişisel tercihleri öne sürmüştür. Tablo 4'te gösterildiği gibi grubun yararını gözeten dışlama davranışının, etnisiteye dayalı bu hikâyede (\%13) cinsiyete dayalı hikâyeye (\%8) nazaran daha ön plana çıktığ 1 ve olumlu değerlendirildiği görülmektedir. 
Tablo 4. Katılımcı Çocukların Dışlanmaya Yönelik Gerekçelerinin Yüzdelik Dağılımı

\begin{tabular}{lll}
\hline Alan & Cinsiyet & Etnisite \\
\hline Ahlaki & 71 & 75 \\
Toplumsal-geleneksel kurallar & 17 & - \\
Grup fonksiyonu ve deneyimler & 8 & 13 \\
Kişisel ve diğer & 4 & 12 \\
\hline
\end{tabular}

3. Kimi seçerler? Oyuncakların sınırlı olduğu hikâyelerde, çocukların toplumsal cinsiyet ve etnisite bağlamlarında, oyun grubuna kimin seçileceğine yönelik kararları ve bu kararlara dayalı gerekçelendirmeleri betimsel analizle incelenmiştir. Tablo 5, katılımcı çocukların oyunda yalnızca bir çocuğa yetecek kadar oyuncak olduğu koşulda, toplumsal cinsiyet hikâyesinde $\% 33$, etnisite hikâyesinde ise \%42 grup-içi seçim yaptıkları göstermektedir. Katılımcı çocuklar, özellikle kız ve oğlan arkadaşları arasında seçim yapmak zorunda kaldıkları durumda ikisini de alabilecekleri alternatifler (\%42) geliştirmişlerdir. Etnisite hikâyesinde ise, katılımcıların her iki çocuğu da aynı anda kapsamaya yönelik daha az alternatif ürettikleri gözlemlenmiştir (\%25), çocuklar daha çok kendi etnik grubundan arkadaşı seçmeye meyil etmişlerdir.

Tablo 5. Katılımcı çocukların hikâyelerde oyuncakların limitli olması durumunda oyun grubuna kimin seçileceğine yönelik değerlendirmelerinin yüzdelik dağılımı

\begin{tabular}{lcc} 
& $\begin{array}{c}\text { Toplumsal } \\
\text { Cinsiyet (\%) }\end{array}$ & Etnisite (\%) \\
\hline Kendi gibi olanı seçer (grup-içi) & 33 & 42 \\
Ötekini seçer(grup-dışı) & 25 & 33 \\
İkisini de seçmeye çalışır & 42 & 25 \\
\hline
\end{tabular}

Tablo 6, katılımcı çocukların oyuncakların limitli olduğu toplumsal cinsiyet hikâyesinde seçtikleri ile seçimlerine yönelik verdikleri gerekçeler arasındaki ilişkiyi göstermektedir. Ahlaki gerekçe sunanların tamamı, seçimlerini karşı cinsi $(\mathrm{N}=4)$ ya da her iki cinsi de oyuna alabilmekten $(\mathrm{N}=7)$ yana yapmıştır. Oyuna hemcinslerini seçenler ise, daha çok toplumsalgeleneksel gerekçeler sunmuşlardır $(\mathrm{N}=7)$. Çocukların, hemcinslerini oyuna seçerken "Herkes kendi grubuyla oynar, erkekler bebeklerle oynamayı daha az sever.", "Kerem' i seçebilirler. Çünkü, belki şöyle düşünürler; oyuncak arabalar daha çok erkeklere göre. Çünkü benim bildiğim kadarıyla arabalarla kuzlardan çok erkekler oynar.", "Selin' i seçerler, çünkü o bebekleri daha çok sever, hem de orada tek bir oyuncak bebek olduğuna göre, araba filan erkek oyuncakları boşta olabilir, o da gidip onlarla oynar. Kerem de gidip daha çok sevdiği oyuncaklarla oynayabilir." gibi toplumsal-geleneksel kalıp yargıları kullandıkları görülmüştür.

Tablo 6. Oyuncakların Limitli Olduğu Toplumsal Cinsiyet Hikâyesinde Oyun Grubuna Kimin Seçileceğine Yönelik Verilen Gerekçelerin Kimin Seçildiğine Göre Frekans Dağılımı

\begin{tabular}{llcl}
\hline & Ahlaki & $\begin{array}{c}\text { Toplumsal- } \\
\text { Geleneksel }\end{array}$ & Kişisel seçim \\
\hline Kendisi gibi olan(grup-içi) & - & 7 & 1 \\
Kendinden farklı olan(grup-diş1) & 4 & - & - \\
Her ikisini de & 7 & 1 & - \\
\hline
\end{tabular}

Tablo 7'de gösterildiği gibi etnisite hikâyesinde de kapsayıcı cevap verenlerin tamamı $(\mathrm{N}=10)$ bunu ahlaki nedenlerle gerekçelendirmiştir. Grup-içi seçim yapanlar ise $(\mathrm{N}=10)$ bunu grubun işleyişi ile gerekçelendirmişlerdir. Çocuklar, oyunda bir diğerini dişlayıp oyuna dahil olacak kişinin oyun grubuna olası katkılarını, yani oyun grubunun çıkarlarını, gözetirken geçmiş 
deneyimlerinden de faydalanmışlar ve bunu "Belki o Türkçe konuşamadiğı için almıyorlar, çünkü konuşarak bir oyun oynuyorlardır ve doğru anlamalarl gerekiyordur, o yüzden almamışlardır.", "Bence Selin' i seçerler, çünkü Selin daha önceden gelmiş o sınıfa ve onun nasıl oynadiğını biliyor diğer çocuklar ve ona alışmış olabilirler.", “Selin' i seçerler, çünkü Türkçe konuşmayı biliyor.", "Selin, çünkü daha cesur görünüyor ve ona daha çok güveniyorum. Rana'yı daha önce de almamışlardı ve yine almayacaklardır oyunu bilmediği için." şseklinde ifade etmişlerdir. Yukarıdaki alıntılarda da görüldüğü gibi çocukların karşılaştıkları sosyal hayat komplike hale geldikçe, oyuncağın yetmemesi ya da grupta sadece bir kişiye yer olması gibi çetrefilli durumlarla karşılaştıklarında ve elde değerlendirmeye katılacak başka bir bilgi olmadığında, değerlendirme yaparken kalıp yargıları, grup işleyişini ve sosyal normları daha sıklıkla kullandıkları bulunmuştur (Killen, 2007)

Tablo 7. Oyuncakların Limitli Olduğu Etnisite Bağlamındaki Hikâyede Oyun Grubuna Kimin Seçileceğine Yönelik Değerlendirmeler ve Gerekçeler Arasındaki Frekans Dağılımı

\begin{tabular}{lccc}
\hline & Ahlaki & Grup Fonksiyonu & Toplumsal- Geleneksel \\
\hline Kendisi gibi olan (grup- içi) & - & 10 & - \\
Kendinden farklı olan (grup- dışı) & 6 & 2 & - \\
Her ikisini de & 4 & 1 & 1 \\
\hline
\end{tabular}

Tablo 8. Çocukların Hikâyelerdeki Dışlanan ve Dışlayana Yönelik Duygu Atıflarının Dağılımının Yüzdelik Dağılımı

\begin{tabular}{lcccc}
\hline & Dişlanan (\%) & \multicolumn{3}{c}{ Dişlayan (\%) } \\
\hline Üzgün & Toplumsal cinsiyet & Etnisite & Toplumsal cinsiyet & Etnisite \\
Kızgın & 92 & 82 & 4 & 13 \\
Şaşkın & 8 & 4 & 46 & 13 \\
Mutlu & - & 14 & - & 17 \\
Diğer & - & - & 46 & 57 \\
\hline
\end{tabular}

4. Duygu atıfları. Hikâyelerde oyundan dışlanan çocuğun duyguları, toplumsal cinsiyet bağlamındaki hikâyede üzgün (\%92) ve kızgın (\%8) olarak tanımlanırken, etnisite bağlamında dışlanan çocuğun duygularına yönelik beklentiler, üzgün (\%82), kızgın (\%4), şaşkın (\%14) olarak ifade edilmiştir. Akranını dışlayana, yani failin duygularına yönelik beklentiler, toplumsal cinsiyet bağlamındaki hikâyede, üzgün (\%4), kızgın (\%46), mutlu (\%46), diğer (\%4) olarak ifade edilmiştir. Etnisiye dayalı hikâyede ise failin duygularına yönelik beklentiler, üzgün (\%13), kızgın (\%13), şaşkın (\%17), mutlu (\%57) olarak bulunmuştur (Tablo 8). Çocuklar dışlanan akranın duygularını ifade ederken "Üzgün. Çünkü oyuna katılmak istemişti, teklif etmişti ve almadılar.”, "Bir parça üzgün hissetmiştir, ağlamaklı değil ama üzgün. Belki arkadaş bulamıyordur ve son bulabildiği kişiler de onlardır.", "Kızgın, çünkü oyuna alınmadl.", "Çok Üzgün ve dışlanmış hissedebilir. Buraya yeni geldiği için kimseyi tanımıyordur ve hiç arkadaşı yoktur. Oynayacak kimsesi olmadiğı için üzgün, kızgın, şaşırmış ve dışlanmış hissetmiş olabilir.", "Üzgün, çünkü oyuna alınmazsa ve teneffüste başka oyun bulamazsa sıkılır ve üzülür.", "Şaşırmış, çünkü normalde kızlar kızları oyuna alır ve şimdi Rana'yı almadıkları için şaşırmıştır." yorumlarını yapmışlardır. Alandaki çoğu araştırma, olumsuz duygular atfeden neredeyse tüm çocukların onları gerçek ahlaki nedenlerle desteklediğini göstermektedir (Arsenio, 2014). Bu, erken ahlaki muhakeme ve duygular üzerine yapılan çalışmalardan elde edilen bulgularla tutarlıdır (Malti ve Dys, 2015). 
Katılımcılar, dışlayan çocuğun duygularını toplumsal cinsiyete dayalı hikâyede mutlu ve kızgın olarak tanımlamış ve bu değerlendirmelerini "Mutlu, çünkü diğerleri onun oynamasını zaten istememişti. Şimdi istedikleri oldu.", "Kızgın ve mutlu. Çünkü zaten bloklarla oynuyordu ve diğerinin gelmek istemesine kızdilar." şeklinde ifade etmişlerdir. Etnisiteye dayalı hikâyede ise katılımcıların, hikâyede akranını dışlayan çocuğun duygusunu mutlu olarak tanımladıkları görülmektedir. Bu duygu atıflarını "Mutlu, çünkü zaten o oynuyordu ve diğerini almadı, oynamaya devam etti.", "Hiç aldırmadan mutlu olabilir. Çünkü onu biri oyundan atmıyor ki, diğerini oyuna katmayınca ona bir şey olmuyor, mutludur.", "Onlar mutlu mesut oynamaya devam etmiştir ya da Rana' ya oyunu böldügü için kızmış olabilirler.", "Mutlu hissetmeye devam ederler, çünkü oyun oynuyorlar, diğeri sadece soruyor. Niye üzülsün ki bir sorudan, mutlu mutlu oynamaya devam etmiştir." şeklinde ifade etmişlerdir. Katılımcıların, dışlayan çocuğun duygularına yönelik olumlu duygu atıfları literatürdeki "mutlu fail" fenomeni ile tutarlidır (Malti ve Dys, 2015).

Tablo 9. Katılımcı Çocukların Oyun Grubundan Dışlananın Kendileri Olması Durumuna Yönelik Çözüm Önerilerinin Yüzdelik Dağılımı

\begin{tabular}{lcc}
\hline & Toplumsal \\
Cinsiyet (\%) & Etnisite (\%) \\
\hline Oyuna katılmak için bir daha sorardım. & 17 & 21 \\
Başkalarıly oynardım. & 52 & 33 \\
Onları uyarırdım. & 4 & 4 \\
Yetişkine şikâyet ederdim. & 13 & 16 \\
Öç alırdım, vururdum. & 4 & 4 \\
Başka oyuncak alırdım. & 4 & 13 \\
Hiçbir şey yapmazdım. & - & 8 \\
Diğer & 4 & - \\
\hline
\end{tabular}

5. Geleceğe yönelik öz-yansıtma. Tablo 9'da gösterildiği gibi çocuklar, kendileri oyun grubuna dahil edilmeme problemiyle karşılaştıklarında ne yapacaklarının sorulduğu soruya şu yanıtları vermişlerdir. Toplumsal cinsiyete dayalı hikâyede, çocukların probleme "Başkalarıyla oynardım. (\%52)", "Oyuna katılmak için bir daha sorardım (\%17)", "Onları uyarırdım (\%4)", "Yetişkine şikayet ederdim (\%13)", "Öç alırdım, vururdum. (\%4)", "Başka oyuncak alırdım." $(\% 4)$ ve diğer (\%4) çözümler getirdiği görülmektedir. Etnisiteye dayalı hikâyede ise, çocukların probleme getirdikleri çözümlerin dağılımları, "Başkalarıla oynardım (\%33)", "Oyuna katılmak için bir daha sorardım (\%21)", "Onları uyarırdım (\%4.2), "Yetişkine şikayet ederdim (\%16)", "Öç alırdım, vururdum." (\%4), "Başka oyuncak alırdım (\%13)" ve "Hiçbir şey yapmazdim (\%8)" olarak analiz edilmiştir.

Çocukların oyun grubundan dışlanma gibi problemle karşılaştıklarında, sorunu çözmek için olumlu ve yapıcı daha proaktif stratejiler önerdikleri görülmüştür. Çocuklar bu probleme getirdikleri çözüm önerilerini "Ben de gidip başka arkadaşlarımla oynardım. ”, "Bir öneri sunardım, bunlardan hepimize yok, başka bir oyun oynayalım derdim." , "Başka çocuk varsa diğerleriyle oynardım, başka çocuk yoksa kendi kendime oynardım, resim çizerdim. ”, "Gidip bir büyügüme söylerdim ya da çocuklara derdim ki; eşitlik olmalı beni de almalısınız.", "Sinıf ögretmenime söylerdim duygumu anlatırdım ve daha iyi hissederdim. " , "Eve gider, başka arkadaşlarımı çağırır oynardım. " şeklinde ifade etmişlerdir. Ancak, katılımcılardan bazılarının, problem durumunda aldıkları pasif konumları da dikkat çekici bulunmuştur. Olumsuz duygularla baş etme yöntemlerinden biri olarak, katılımcı çocukların bilgisayar oyunlarını tercih etmelerinin de dikkat çekici olmasıyla birlikte başka bir araştırmanın konusu olarak incelenmeye değer olduğu düşünülmektedir. Çocuklar bu 
çözümlerini “Beni oyuna almazlarsa üzülürdüm, eve gidip playstation oynardım.”, "Üzgün olurdum ve de eve gidip koltukta yatardım. Anneme yalvarıp biraz ipade bakardım." şeklinde ifade etmişlerdir. Çocukların grup içinde problemle karşılaştıkları durumlara yönelik "Öç alırdım, vururdum. " yanıtları az rastlanan bir çözüm önerisi olmakla birlikte, hak, adalet, eşitlik durumlarının sağlanamadığı ortamlarda karşılaşılan ve bastırılmış olan saldırganlığın isyankar ve adalet arayışının eylemle olmasa dahi kelimelerle ifadesi, eyleme geçişe dair arzu ve fantezi olarak yorumlanabilir.

$\mathrm{Bu}$ araştırmada, ortaya çıkan şaşırtıcı bulgulardan biri de oyuncakların limitli olduğu hikâyelerde, çocukların limitli- sınırlı oyuncak açıklamasını yok saymaları ya da bu varsayımı dikkate almaksızın çözüm bulmaları olmuştur. Bu bulgunun katılımcı çocukların ailelerinin yüksek gelir seviyesine sahip olmaları ve yokluk deneyimine sahip olmamaları ile yakından ilişkili olduğu düşünülmektedir. Çocuklar, oyuncakların limitli olduğu durumlarda kendilerinin dışlanan çocuk olmalarına ilişkin çözüm önerilerini, "Üzülürdüm, sonra marketten alırdım yeni oyuncak, sonra gelir onlarla oynardım.", "Daha fazla kamyon isterdim ve o kamyonu alıp onunla oyuna katılırdım.", "Başka bloklar alır kendim oynardım.", "Başka bir oyuna geçerdim ya da başka bir oyuncak getirirdim kendim.", "Başka bir blok bulurdum ya da başka oyuna geçerdim.", "Başka, yeni bir oyuncak alırdım, araba mesela. Onlar belki garaj yaparlardı, ben de onlara katılırdım.", "Öğretmene gidip başka oyuncaklarla oynayabilir miyim diye sorardım", "Başka bir çocuk arardım ve onunla arkadaş bulurdum. Anne ve babama bir tane arkadaş bulabilir misiniz benim için, derdim. ” şeklinde ifade etmişlerdir.

Literatürdeki araştırmalar da yukarıdaki bulguları destekler niteliktedir. Killen ve Ruthland (2013), Sosyal Alan Kuramını kullanarak gruplar arası ilişkilerin ve sosyal dışlamanın nasıl geliştiğini inceledikleri kitaplarında, çocukların ahlaki ve toplumsal kavramları inşa ederken, çoğunluğun, kendinden başkası yani ötekiyle olan ilişkisinin ve grup dinamiklerinin önemli rol oynadığına yer verirler. Çocuk, ilk olarak kendi küçük ve büyük ailesinde, çevresinde, dışarıda ve ardından akranlarıyla buluştuğu okuldaki sosyal yaşamında ötekiyle karşılaşır. Çocuk, bu sosyal etkileşim süreçlerinde farklı sosyal grupların içinde kendini bulur ve gerek aileden getirdiği kurallar ve deneyimler ile, gerekse aile dışındaki sosyal gruplar içindeki etkileşimlere dayanarak birtakım yargılar geliştirir. Bu yargılar dahilinde ötekini sosyal gruplara dahil etme veya ötekini bu sosyal gruplardan dışlama eylemlerinde bulunur. Mevcut çalışmada da çocuklar, farklı sosyal gruplarla girdikleri etkileşimlerde bir yandan eşitlik, hak, adalet, iyi oluş hali gibi ahlaki prensipleri gözeterek kapsayıcı olmanın gerekliliği üzerinde değerlendirmelerde bulunmuş, aynı zamanda grup aidiyeti dışında ek bir bilginin olmadığ 1 karmaşık ya da belirsiz durumlarda kendi değerlendirme sistemlerindeki toplumsal-geleneksel normları ve kalıp yargıları kullanarak dışlama eğiliminde olmuşlardır (Killen vd., 2002). Bu durumun, yani grup içi ve grup dışı ayrımının oyuncakların limitli olduğu etnisiteye dayalı hikâyede daha ön plana çıktığ1 görülmektedir.

\section{SONUÇ VE ÖNERILLER}

Araştırmanın bulguları, katılımcı çocukların toplumsal cinsiyete ve etnisiteye dayalı her iki hikâyede de akranını oyun grubuna dahil etmeme-dışlama davranışını ahlaki açıdan uygun bulmadıklarını göstermektedir. Öte yandan katılımcı çocukların, sadece bir arkadaşa yetecek kadar oyuncak olduğu durumlarda, ötekinin iyi oluşu ve adalet gibi ahlaki prensipleri ikinci plana atıp toplumsal cinsiyetle ilgili kalıp yargıları ya da grup işleyişini ön plana çıkarmaya daha eğilimli oldukları bulunmuştur. Bu bulgular alanyazınla tutarlı olmakla birlikte (Killen ve Ruthland, 2013), akran dışlanmasına yönelik sosyal ve ahlaki sorgulamanın ülkemizdeki gelişim örüntüsünü ortaya çıkarmak için çocuk ve genç katılımlı daha kapsamlı çalışmalar yapılmalıdır. Öte yandan, bu çalışmanın Sosyal Alan Kuramının ahlaki ve toplumsal-geleneksel ayrışması açısından incelediğimizde özellikle oyuncağın limitli olduğu durumlarda seçimini dış gruptan yana kullanan çocukların ötekine fırsat eşitliği sağlama gibi gerekçelerde ortaklaştıkları 
gözlemlenmiştir. Çocukların bu gerekçeleri kuramın ahlaki alan tanımıyla tutarlıdır (Turiel, 1983).

Bu çalışmanın bir diğer bulgusu, sekiz yaş grubu Türkiye örnekleminde de mutlu fail olgusunun gözlenmesidir. Önceki araştırmalar (Arsenio ve Krammer, 1992; Keller vd., 2003), mutlu fail olgusunun dört-sekiz yaşlarında gözlemlendiğini, sekiz yaş itibariyle faile atfedilen olumlu duyguların yerini suçluluk duygusu, üzüntü, vicdan azabı gibi ahlaki duygulara bıraktığını göstermektedir. Bu açıdan bakıldığında, mevcut çalışmanın çalışma grubunun ilkokul ikinci sınıf öğrencilerinin oluşturduğu düşünüldüğünde mutlu fail olgusunun dönüşümünün daha temsili bir örneklemde boylamsal ve kesitsel desenlerle araştırılması gereklidir.

Üzerinde yaşadığımız coğrafya ve içinde bulunduğumuz toplum farklı kültürleri, inançları, etnik farklılıkları kapsamaktadır. Böyle bir toplumda, ötekini anlamak, grubun içine dahil edebilmek ve kendinin ve ötekinin iyilik, esenlik durumunu gözetebilen "biz" bilincini oluşturabilmek, değişen ve gelişen dünyada hak, adalet, eşitlik ve birlikte var olabilme kavramlarına sahip çıkabilmek adına oldukça önemlidir. Çocukların ötekine karşı yargılarının erken çocukluk döneminden itibaren oluştuğu göz önünde bulundurularak, öncelikle bireyi ötekileştiren ve tanımlayan dil kullanımının ne zaman ortaya çıktığı daha çok araştırılmalıdır. Grup aidiyetini ve işleyişinin ön plana çıkmaya başlaması özellikle toplumsallaşmanın ve arkadaş ilişkilerinin önem kazandığı ilkokul yıllarına denk gelir ve ergenlik dönemiyle birlikte ortaklaşan amaç, ilgi ve yetenekler arkadaş gruplarının odağı olur (Killen, Lee-Kim, McGlothin ve Stangor, 2002). Bu bağlamda, Türkiye çalışma grubunda grup işleyişi ve aidiyetinin okul öncesi ve ilkokul yılları boyunca nasıl değiştiğini araştırmak elzemdir.

$\mathrm{Bu}$ çalışmanın en önemli kısıtlılıklarından biri, verilerin özel okulda küçük bir çalışma grubundan toplanmış olmasıdır. Çocukların içinde büyüdükleri aile, sosyal gruplar, yakın ve uzak çevreleri ve başkalarıyla olan iletişimleri, onların sosyal ilişkilerin dinamiklerini anlama, anlamlandırma ve değerlendirmelerinde etkilidir. Motivasyonel değişkenlerin rolü, ekonomik gelir seviyesi, ebeveynlerin eğitim seviyesi, ebeveyn tutumları da çalışmanın bulgularını etkileyebilecek faktörlerdir. Buna dayanarak, belli bir grubun katılımıyla gerçekleşen bu araştırmanın sonuçlarını genellemek oldukça zordur. Farklı sosyo-kültürel ve ekonomik gelir seviyesine sahip gruplarla ulusal yazında daha geniş ve daha fazla araştırmaya ihtiyaç duyulmaktadır. Söz konusu çalışma grubunda, öğrencilere farklı sosyal gruplarda, projelerde ve aktivitelerde cinsiyeti, etnisiteyi veya herhangi bir farklılığı gözetmeksizin eşit haklar ve fırsatlar sunulmaktadır. Bu çerçeveden bakıldığında etnisite hikâyesinin kahramanı Rana ve ailesinin Türkiye' ye sığınmak zorunda kaldığı bilgisi verilmiş ama Suriyeli olduğu bilgisi açık olarak paylaşılmamıştır. Bu durumda, bazı katılımcı çocuklar göçmen çocuğu daha çok expat çocuğu olarak algılamış ve hiyerarşik bir ilişkilendirme yapmamışlardır, değerlendirmelerini yaparken kendi çevrelerindeki "yabancı" arkadaşlarından örnekler vermişlerdir. Araştırmaya katılan çocukların akran ilişkilerine dayalı konuları değerlendirmelerinde ve gerekçelendirmelerinde sunmuş oldukları argümanlarda, aile içinde ve okullarında almış oldukları eğitimin olumlu bir etkisi olduğu düşünülse de toplumun geneli tarafindan dışlandığını bildiğimiz farklı gruplar için geçerli olup olmadığı bilinmemektedir.

Mevcut araştırmanın kısıtlılıklarından biri de kullanılan hikâye içeriklerinin belli oyun araçları etrafında oluşturulmasıdır (oyuncak bebek, arabalar ve bloklar). Bu hikâyeler spor, müzik, sanat gibi faaliyetlerde dışlanma pratiklerini araştıracak şekilde genişletilebilir. Toplumsal cinsiyet rollerininin, etnisitenin veya fiziksel engeller gibi farklılıkların birlikte soruşturulduğu araştırmaların Türkçe alanyazına katkı sağlayacağı düşünülmektedir. Çevrimiçi yürütülen araştırmada, katılımcıların çoğu araştırmacı ile birebir görüşmüştür, ancak birkaç katılımcının görüşme kaydını açma-kapama, teknik destek alma amacıyla yanında bir yetişkin ile görüşmeye katıldı̆̆ 1 görülmüştür. Katılımcıya teknik destek veren yetişkinin katılımcının kararlarına 
herhangi bir müdahalesi olmasa da bu durumun katılımcının kararını düşük bir yüzde olmakla birlikte etkileyebileceği düşünülmektedir.

Mevcut araştırmada, oyuncakların limitli olduğu hikâyelerde, çocukların bazılarının limitlisınırlı oyuncak açıklamasını yok saymaları ya da bu varsayımı dikkate almaksızın çözüm bulmaları da dikkat çekici bulunmuştur. Bu bulgunun, katılımcı çocukların ailelerinin yüksek gelir seviyesine sahip olmaları ve yokluk deneyimine sahip olmamalarıyla ilişkili olduğu düşünülmektedir. Bu varsayım göz önünde bulundurulduğunda, ailelere ve eğitimcilere, çocuklara hem kendi ayrıcalıklı pozisyonlarının hem de toplumsal adaletsizliklerin farkına varabilecekleri sabır- sebat, imkanlar ve imkansızlıklar gibi konulara aile içi etkileşimlerde ve okullarda sosyal duygusal öğrenme etkinlikleri dahilinde müfredata sıklıkla yer verilmesi önerilmektedir.

Mevcut çalışma, varsayımsal hikâyeler üzerinden yürütülmüştür, dolayısıyla çocukların benzer durumları bizzat yaşamaları durumunda olası tepkilerini tamamen yansitmayabilirler. Ancak, henüz davranışa yansımasa bile bilişsel süreçlerde, çocukların birtakım davranışlara yönelik yargılarda bulunması oldukça önemlidir. Çocuklar, henüz gerçek yaşam deneyimlerinde hikâye üzerinden konuştukları gibi davranmasalar bile, bu yargılama becerisinin bilişsel süreçlerde çocukların gündeminde olduğu görülmektedir. Okulların Psikolojik Danışmanlık ve Rehberlik Birimi uzmanlarının öğrenci çalışmalarında bu yargılama ve değerlendirme yöntemlerini kullanarak çocuklarla sıklıkla ve bir plan dahilinde çalışmaları önerilmektedir. Buna ek olarak okul psikolojik danışmanlık birimleri ailelere de çocukların sosyal ve ahlaki sorgulama becerilerini nasıl destekleyecekleri konusunda rehberlik edebilir.

Türkiye, son yıllarda yoğun bir şekilde genç nüfus ağırlıklı göç almaktadır ve bununla birlikte yaş ortalaması okul çağında olan göçmen çocuk sayısı gün geçtikçe artmaktadır. Temel hakları olan eğitim- öğretimi almak adına, farklı şartlar ve koşullar dahilinde, göçmen çocuklar da yaşamakta oldukları bu yeni sınırlar içinde okula gitmektedirler. Göçmen çocuklar ve burada hali hazırda eğitim- öğretim gören çocuklar, sokakta ve okulda gerek grup içinden gerekse grup dışından akranlarıyla yan yana gelmektedir. Toplumsal-geleneksel kuralların ve kalıp yargıların bu bağlam içinde, grup dışından olan akrana tutumları da önemli ölçüde etkileyebileceği düşünülmektedir. Göçmen çocuklarının buradaki akran çocuklarıyla ilişkisi, buradaki çocukların göçmen çocuklara karşı inanış ve tutumlarını incelemenin oldukça önemli olduğu düşünülmekte ve gelecek araştırmalar için önem arz eden bir konu olarak önerilmektedir. Üzerinde araştırılması ve çalışılması gereken bu konunun daha kapsayıcı ve demokratik bir okul ikliminin ve bununla ilişkili olarak daha kapsayıcı ve demokratik bir toplumun temellerini oluşturması açısından oldukça önemli olduğu düşünülmektedir. 


\section{KAYNAKÇA}

Arsenio, W. (2014). Moral emotion attributions and aggression. Handbook of moral development, 2, 235-255.

Arsenio, W. F., \& Kramer, R. (1992). Victimizers and their victims: Children's conceptions of the mixed emotional consequences of moral transgressions. Child Development, 63(4), 915-927.

Arsenio, W., \& Lover, A. (1995). Children's conceptions of sociomoral affect: Happy victimizers, mixed emotions, and other expectancies. In M. Killen \& D. Hart (Eds.), Morality in everyday life: Developmental perspectives (pp. 87-128). Cambridge University Press.

Bayraktar, F. (2006). İlköğretimde zorbalık ve kurban olma: Ergenlik öncesi çocuklarda zorbaların, kurbanların, zorba/kurbanların ve katılmayan grubun karşılaştırılması. Türk Psikoloji Bülteni, 38, 43-58.

Creswell, J. W., \& Clark, V. L. P. (2017). Designing and conducting mixed methods research. Sage Publications.

Gummerum, M., Lopez-Perez, B., Ambrona, T., Rodríguez-Cano, S., Dellaria, G., Smith, G., \& Wilson, E. (2016). Children's moral emotion attribution in the Happy Victimizer task: The role of response format. The Journal of Genetic Psychology, 177(1), 1-16.

Keller, M., Lourenço, O., Malti, T., \& Saalbach, H. (2003). The multifaceted phenomenon of 'happy victimizers': A cross-cultural comparison of moral emotions. British Journal of Developmental Psychology, 21(1), 1-18.

Killen, M. (2007). Children's social and moral reasoning about exclusion. Current Directions in Psychological Science, 16(1), 32-36.

Killen, M., Lee-Kim, J., McGlothlin, H., \& Stangor, C. (2002). How children and adolescents evaluate gender and racial exclusion. Monographs of the Society for Research in Child Development, 1-129.

Killen, M., Mulvey, K. L., \& Hitti, A. (2013). Social exclusion in childhood: A developmental intergroup perspective. Child Development, 84(3), 772-790.

Killen, M., \& Rutland, A. (2013). Children and social exclusion: Morality, prejudice, and group identity. John Wiley \& Sons.

Killen, M., \& Stangor, C. (2001). Children's social reasoning about inclusion and exclusion in gender and race peer group contexts. Child development, 72(1), 174-186.

Kohlberg, L. (1969). Stage and sequence: The cognitive-developmental approach to socialization. In D. A. Goslin, (Ed.), Handbook of socialization theory and research, pp. 347-480, Chicago, IL: Rand McNally.

Köymen, B., Tomasello, M. (2017). Çocuklar sosyal normları nasıl algılar, Ç. Aydın, T. Göksun, A. Küntay ve D. Tahiroğlu (Derleyenler), Aklın çocuk hali: Zihin gelişimi araştırmaları, (ss. 233-248). İstanbul: KÜY Yayınevi.

Malti, T., \& Dys, S. P. (2015). A developmental perspective on moral emotions. Topoi, 34(2), 453-459.

Mayer, S.J. (2005). The early evolution of Jean Piaget's clinical method. History of Psychology, 8(4), 362.

Nucci, L. (1981). Conceptions of personal issues: A domain distinct from moral or societal concepts. Child Development, 114-121.

Piaget, J. (1932). The moral judgment of the child. New York: McGraw-Hill.

Killen, M., \& Rutland, A. (2013). Children and social exclusion: Morality, prejudice, and group identity. John Wiley \& Sons.

Smetana, J. G. (1981). Preschool children's conceptions of moral and social rules. Child Development, 1333-1336. 
Smetana, J. G. (1989). Toddlers' social interactions in the context of moral and conventional transgressions in the home. Developmental Psychology, 25(4), 499.

Smetana, J. G. (2005). Social-cognitive domain theory: Consistencies and variations in children's moral and social judgments. In M. Killen \& J. Smentana (Eds.), Handbook of moral development. Psychology Press.

Theimer, C. E., Killen, M., \& Stangor, C. (2001). Young children's evaluations of exclusion in gender-stereotypic peer contexts. Developmental Psychology, 37(1), 18.

Turiel, E. (1983). The development of social knowledge: Morality and convention. Cambridge University Press.

Turiel, E. (2015). Moral development. Handbook of child psychology and developmental science, 1-39.

Yaşartürk, İ. (2019). Illkokul öğrencilerinin adalet, dürüst olma, sorumluluk ve yardımseverlik değerlerine yönelik yargılarının Kohlberg'in ahlak gelişim kuramına göre incelenmesi, Yüksek lisans tezi, Sakarya Üniversitesi Sosyal Bilimler Enstitüsü, Sakarya. 